\title{
Interrelations between cerebrospinal fluid and plasma inorganic ions and glucose in patients with chronic renal failure
}

\author{
IF PYE,* GM ABER \\ From the Departments of Neurology and Nephrology, Department of Postgraduate Medicine, University of \\ Keele, North Staffordshire Hospital Centre, Hartshill, Stoke-on-Trent ST4 7NY
}

SUMMARY The concentrations of inorganic ions and glucose in the plasma and CSF of 11 patients with "steady-state" chronic renal failure have been measured and their CSF:plasma interrelations studied. The results have been compared with the corresponding data from 34 control subjects.

In the patients with renal failure, there was a positive correlation between raised CSF and plasma potassium concentrations. In contrast to the impaired potassium homeostasis, normal CSF magnesium and calcium concentrations were observed despite wide variations in the plasma concentrations of these ions.

Selective abnormalities of the cerebrospinal fluid (CSF) amino acids have been reported in patients with chronic renal failure. ${ }^{1}$ It has been suggested that this finding represents an alteration of amino acid transport between CSF and plasma. The present study was designed to examine whether a parallel situation exists in renal disease, for inorganic ions and glucose. Their concentrations and distribution between CSF and plasma have been compared in normal subjects and in patients with "steady-state" chronic renal failure.

\section{Patients and methods}

The concentrations of sodium, potassium, chloride, calcium, magnesium, glucose and protein were measured in simultaneously collected aliquots of CSF and plasma.

\section{CONTROLS}

Thirty-four control subjects (15 males, 19 females; mean age $34.5 \mathrm{yr}$, range 14-67 yr) who presented with potentially significant headache or low back pain and were shown subsequently to be normal by clinical neurological criteria and investigations including biochemical and cytological analysis of the CSF. A lumbar puncture formed part of the investigations required to exclude structural neuro-

*Present address: Department of Neurology, Leicester Royal Infirmary, Leicester LE1 5WW.

Accepted for publication 28 October 1981 logical disease. None of these individuals had any evidence of metabolic or systemic disease and all were on a normal diet.

PATIENTS

Eleven patients with "steady-state" chronic renal failure ( 6 males, 5 females; mean age $45.4 \mathrm{yr}$, range 30-70 yr) (Table 1). The criteria of "steady-state" were that three successive measurements of plasma urea and serum creatinine were stable over a period of not less than seven days while on a constant daily protein intake of 40 to $50 \mathrm{~g}$. None of the patients was being treated by haemodialysis. The mean plasma urea and serum creatinine concentrations were $40 \cdot 5$ $\mathrm{mmol} / \mathrm{l}$ and $1070 \mu \mathrm{mol} / \mathrm{l}$ respectively. Two of the patients had been taking diuretics for control of hypertension but their plasma electrolyte concentrations did not differ from those of the other patients in this group and had been stable during the nine months immediately preceding the study. None of the 11 patients was receiving any other drug which might influence plasma electrolyte or urea concentrations. The daily sodium intake ranged from 60 to $100 \mathrm{mmol}$. Ten of the patients had clinical or electrophysiological evidence of a peripheral neuropathy. CSF examination formed part of the investigation of the neuropathy in seven of the patients and in the remaining four, lumbar puncture was performed with the informed consent of the individual. All 11 patients had normal CSF cytology and serology. 
Table 1 Details of patients with "steady-state" chronic renal failure

\begin{tabular}{|c|c|c|c|c|c|c|}
\hline Patients & Sex & Age (yrs) & $\begin{array}{l}\text { Plasma urea } \\
(\mathrm{mmol} / \mathrm{l})\end{array}$ & $\begin{array}{l}\text { Serum creatinine } \\
(\mu \mathrm{mol} / \mathrm{l})\end{array}$ & Plasma pH & Diagnosis \\
\hline 1 & $\mathbf{M}$ & 30 & $27 \cdot 1$ & 1264 & $7 \cdot 30$ & Chronic renal failure of unknown cause \\
\hline 2 & $\mathbf{M}$ & 33 & $25 \cdot 0$ & 1025 & $7 \cdot 31$ & Chronic glomerulonephritis \\
\hline 3 & $\mathbf{M}$ & 36 & $43 \cdot 8$ & 1326 & $7 \cdot 25$ & Chronic glomerulonephritis \\
\hline 4 & $\mathbf{M}$ & 39 & $43 \cdot 3$ & 1387 & $7 \cdot 24$ & Chronic glomerulonephritis \\
\hline 5 & $\mathrm{~F}$ & 40 & $15 \cdot 5$ & 362 & $7 \cdot 22$ & Accelerated hypertension \\
\hline 6 & $\mathrm{~F}$ & 42 & $71 \cdot 6$ & 1326 & $7 \cdot 18$ & Hypertension \\
\hline 7 & $\mathrm{~F}$ & 46 & $25 \cdot 6$ & 875 & $7 \cdot 27$ & Accelerated hypertension \\
\hline 8 & $\mathrm{~F}$ & 50 & $37 \cdot 0$ & 1010 & $7 \cdot 28$ & Polycystic disease \\
\hline 9 & $\mathbf{M}$ & 56 & $65 \cdot 0$ & 1202 & $7 \cdot 22$ & Chronic pyelonephritis \\
\hline 10 & $\mathrm{~F}$ & 57 & $23 \cdot 0$ & 610 & $7 \cdot 28$ & Polycystic disease \\
\hline 11 & $\mathbf{M}$ & 70 & $85 \cdot 0$ & 1396 & $7 \cdot 20$ & Chronic renal failure of unknown cause \\
\hline Mean & & $45 \cdot 4$ & $40 \cdot 5$ & 1070 & $7 \cdot 25$ & \\
\hline SD & & $12 \cdot 0$ & $19 \cdot 9$ & 340 & 0.04 & \\
\hline
\end{tabular}

Table 2 Comparison of plasma and CSF inorganic ion, glucose and protein concentrations (mean $\pm S D)$ in 34 control subjects and 11 patients with "steady-state" chronic renal failure

\begin{tabular}{|c|c|c|c|c|c|c|c|}
\hline & \multicolumn{2}{|l|}{ Plasma } & \multicolumn{2}{|l|}{$C S F$} & \multicolumn{2}{|c|}{ CSF:Plasma ratio } & \multirow[t]{2}{*}{$R_{\text {Dial }} \dagger^{\dagger}$} \\
\hline & Controls & Renal failure & Controls & Renal failure & Controls & Renal failure & \\
\hline Sodium & $139 \cdot 8$ & $141 \cdot 7$ & $147 \cdot 1$ & $149 \cdot 2$ & 1.05 & 1.05 & 0.945 \\
\hline$(\mathrm{mmol} / \mathrm{l})$ & $\begin{array}{r}2 \cdot 78 \\
+2\end{array}$ & 3.04 & +2.58 & \pm 3.66 & +0.02 & 0.02 & \\
\hline Potassium & $3 \cdot 96$ & $4 \cdot 85^{* * *}$ & $2 \cdot 84$ & $3 \cdot 06^{* *}$ & 0.72 & $0.65^{* *}$ & 0.96 \\
\hline$(\mathrm{mmol} / \mathrm{l})$ & \pm 0.32 & 土. 0.86 & $\begin{array}{r}0.18 \\
+5\end{array}$ & \pm 0.22 & $\$ 0.07$ & +0.08 & \\
\hline Chloride & $103 \cdot 0$ & $108 \cdot 5^{*}$ & $123 \cdot 1$ & $129 \cdot 2 * * *$ & $1 \cdot 20$ & $1 \cdot 19$ & $1 \cdot 04$ \\
\hline$(\mathrm{mmol} / \mathrm{l})$ & $\begin{array}{r}3 \cdot 24 \\
\end{array}$ & \pm 5.01 & \pm 2.62 & $\begin{array}{r}+3.92 \\
\end{array}$ & 0.04 & $\div 0.04$ & \\
\hline Magnesium & 0.83 & $1 \cdot 02 * * *$ & $1 \cdot 12$ & $1 \cdot 17$ & $1 \cdot 35$ & $1 \cdot 22$ & $0 \cdot 80$ \\
\hline$(\mathrm{mmol} / \mathrm{l})$ & +0.05 & \pm 0.23 & \pm 0.07 & \pm 0.13 & +0.10 & $+0 \cdot 32$ & \\
\hline Calcium & $2 \cdot 38$ & $1 \cdot 95^{* * *}$ & $1 \cdot 31$ & $1 \cdot 38$ & 0.55 & $0 \cdot 72^{* * *}$ & $0 \cdot 65$ \\
\hline$(\mathrm{mmol} / \mathrm{l})$ & +0.12 & $\div 0.29$ & $\div 0.11$ & 0.13 & 0.06 & $0 \cdot 10$ & \\
\hline Glucose & $4 \cdot 41$ & $5 \cdot 26$ & $3 \cdot 34$ & 3.81 & 0.76 & 0.73 & 0.97 \\
\hline$(\mathrm{mmol} / \mathrm{l})$ & +0.63 & $2 \cdot 32$ & \pm 0.32 & $+1 \cdot 25$ & \pm 0.11 & 0.15 & \\
\hline Protein & $74 \cdot 5$ & $66 \cdot 1^{* * *}$ & 0.29 & 0.32 & 0.004 & $0.005^{* * *}$ & - \\
\hline$(\mathrm{g} / \mathrm{l})$ & $\pm 5 \cdot 2$ & $+5 \cdot 5$ & \pm 0.05 & $\therefore 0 \cdot 10$ & 0.0007 & $: 0.0014$ & \\
\hline
\end{tabular}

†Davson. 11

$* * * \mathrm{p}<0.01$

$* * 0.02>p>0.01$

$* 0.05>p>0.02$

COLLECTION AND ANALYSIS OF SPECIMENS

Samples of CSF and blood were collected simultaneously with the control subjects and renal patients resting in bed after a 12-hour overnight fast. Measurements of CSF and plasma sodium, potassium, chloride, calcium, glucose and protein concentrations were performed using standard methods. The magnesium concentration was estimated by atomic absorption spectrophotometry.

\section{STATISTICAL ANALYSIS OF RESULTS}

The CSF and plasma concentrations and the CSF: plasma concentration ratios $\left(\mathrm{R}_{\mathrm{CSF}}\right)$ of the inorganic ions, glucose and protein were compared in control subjects and renal patients by the Wilcoxon rank sum test. Interrelations of CSF and plasma concentrations were assessed by measurement of the linear (product-moment) correlation coefficient. Comparison of the regression coefficients with the CSF:plasma ratios in the control subjects and renal patients was performed by Student's $t$ test but when the variances were unequal, the "d" test was used." The ranges of control plasma and CSF potassium concentrations were compared by Mood's test ${ }^{3}$ after the difference of each plasma or CSF value from its respective median value had been ranked on a combined scale for the CSF and plasma data.

\section{Results}

In Table 2 the CSF and plasma inorganic ion, glucose and protein concentrations and their CSF: plasma concentration ratios are compared in the control subjects and in the patients with "steadystate" chronic renal failure.

\section{CONTROLS}

In CSF, the mean concentrations of sodium, chloride and magnesium were higher and those of potassium, calcium and glucose were lower than in plasma ( $p<0.01$ in each case). There was a significantly narrower range of potassium concentrations in CSF 


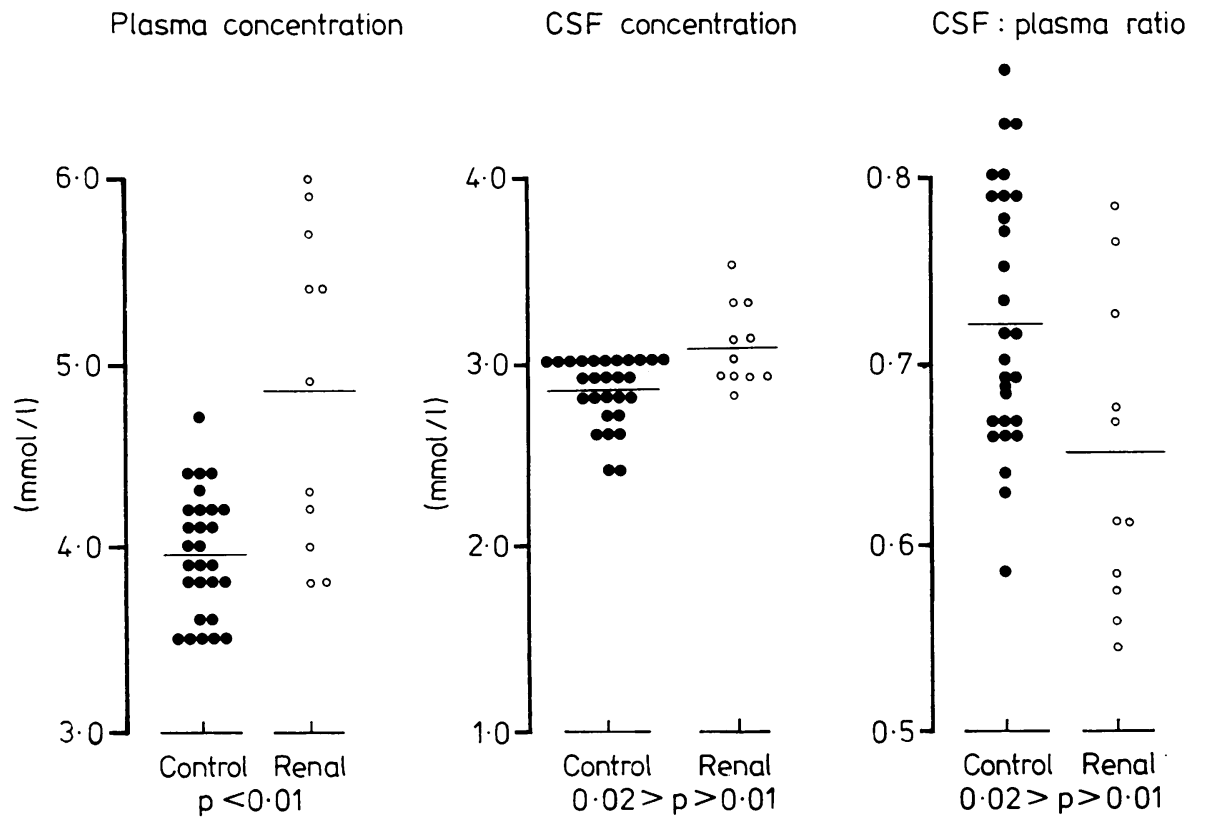

Fig. 1 Plasma and CSF concentrations and CSF:plasma concentration ratios of potassium in control subjects and patients with chronic renal failure.

$(2 \cdot 40-3 \cdot 00 \mathrm{mmol} / \mathrm{l})$ than in plasma $(3 \cdot 50-4 \cdot 70$ $\mathrm{mmol} / \mathrm{l})(\mathrm{p}<0.01)$ (Fig. 1). The CSF concentrations of sodium, chloride and glucose showed a positive correlation with those of plasma $(p<0.05$, $\mathrm{p}<0.01$ and $\mathrm{p}<0.05$ respectively), whereas no such relation was found between the CSF and plasma concentrations of potassium, magnesium, calcium and protein (Table 3 ).
PATIENTS WITH CHRONIC RENAL FAILURE The plasma and CSF concentrations of sodium and glucose and their CSF:plasma ratios did not differ significantly from normal in the patients with renal failure. The CSF protein concentration did not differ from normal in renal failure but the CSF:plasma ratio was increased $(p<0.01)$, reflecting the lower plasma protein concentration of the renal patients

Table 3 Relations between the CSF and plasma concentrations of inorganic ions, glucose and protein in 34 control subjects and 11 patients with "steady-state" chronic renal failure

\begin{tabular}{|c|c|c|c|c|c|c|c|}
\hline & & \multicolumn{2}{|c|}{ CSF:Plasma ratio } & \multirow[t]{2}{*}{ Linear regression equation } & \multirow[t]{2}{*}{ Correlation coefficient } & \multirow[t]{2}{*}{$p 1$} & \multirow[t]{2}{*}{$p 2$} \\
\hline & & Mean & $S D$ & & & & \\
\hline Sodium & $\begin{array}{l}\text { Control } \\
\text { Renal }\end{array}$ & $\begin{array}{l}1 \cdot 05 \\
1 \cdot 05\end{array}$ & $\begin{array}{l}0.02 \\
0.02\end{array}$ & $\begin{array}{l}y=93.63+0.383 x \\
y=49.94+0.700 x\end{array}$ & $\begin{array}{l}0.420 \\
0.582\end{array}$ & $\begin{aligned} & 0.05>p>0.025 \\
> & 0.05\end{aligned}$ & $\begin{array}{l}<0.001 \\
<0.01\end{array}$ \\
\hline Potassium & Control & $0 \cdot 72$ & 0.07 & $y=2.47+0.093 x$ & $0 \cdot 173$ & $>0.1$ & $<0.001$ \\
\hline & $\begin{array}{l}\text { Renal } \\
\text { Control }\end{array}$ & $\begin{array}{l}0.65 \\
1.20\end{array}$ & 0.08 & $y=1.97+0.226 x$ & 0.882 & $<0.001$ & $<0.001$ \\
\hline Chloride & $\begin{array}{l}\text { Control } \\
\text { Renal }\end{array}$ & $\begin{array}{l}1 \cdot 20 \\
1 \cdot 19\end{array}$ & $\begin{array}{l}0.04 \\
0.04\end{array}$ & $\begin{array}{l}y=82.26+0.396 x \\
y=73.34+0.515 x\end{array}$ & $\begin{array}{l}0.506 \\
0.658\end{array}$ & $\begin{array}{r}<0.01 \\
0.05>p>0.025\end{array}$ & $\begin{array}{l}<0.001 \\
<0.001\end{array}$ \\
\hline Magnesium & $\begin{array}{l}\text { Control } \\
\text { Renal }\end{array}$ & $\begin{array}{l}1 \cdot 35 \\
1 \cdot 22\end{array}$ & $\begin{array}{l}0 \cdot 10 \\
0 \cdot 32\end{array}$ & $\begin{array}{l}y=0.78-0.41 x \\
y=1.26-0.094 x\end{array}$ & $\begin{array}{r}0.282 \\
-0.173\end{array}$ & $\begin{array}{l}>0.2 \\
>0.05\end{array}$ & $\begin{array}{l}<0.001 \\
<0.001\end{array}$ \\
\hline Calcium & $\begin{array}{l}\text { Control } \\
\text { Renal }\end{array}$ & $\begin{array}{l}0.55 \\
0.72\end{array}$ & $\begin{array}{l}0.06 \\
0.10\end{array}$ & $\begin{array}{l}y=1.85-0.226 x \\
y=1.00+0.194 x\end{array}$ & $\begin{array}{r}-0.233 \\
0.459\end{array}$ & $\begin{array}{l}>0.2 \\
>0.05\end{array}$ & $\begin{array}{l}<0.001 \\
<0.001\end{array}$ \\
\hline Glucose & $\begin{array}{l}\text { Control } \\
\text { Renal }\end{array}$ & $\begin{array}{l}0 \cdot 76 \\
0 \cdot 73\end{array}$ & $\begin{array}{l}0 \cdot 11 \\
0 \cdot 15\end{array}$ & $\begin{array}{l}y=2.47+0.193 x \\
y=1.06+0.509 x\end{array}$ & $\begin{array}{l}0.382 \\
0.905\end{array}$ & $\begin{array}{l}0.05>p>0.025 \\
<0.001\end{array}$ & $\begin{array}{l}<0.001 \\
<0.005\end{array}$ \\
\hline Protein & $\begin{array}{l}\text { Control } \\
\text { Renal }\end{array}$ & $\begin{array}{l}0.004 \\
0.005\end{array}$ & $\begin{array}{l}0.0007 \\
0.0014\end{array}$ & $\begin{array}{l}y=0.29-0.0 x \\
y=0.07+0.004 x\end{array}$ & $\begin{array}{r}-0.003 \\
0.216\end{array}$ & $\begin{array}{l}>0.9 \\
>0.05\end{array}$ & $\begin{array}{l}<0.001 \\
>0.5\end{array}$ \\
\hline
\end{tabular}

$\mathbf{x}=$ plasma concentration, $\mathbf{y}=\mathbf{C S F}$ concentration.

p1 is the probability of the correlation coefficient.

p2 is the probability of the difference between the observed regression coefficient and the mean CSF:plasma ratio having arisen by chance. 

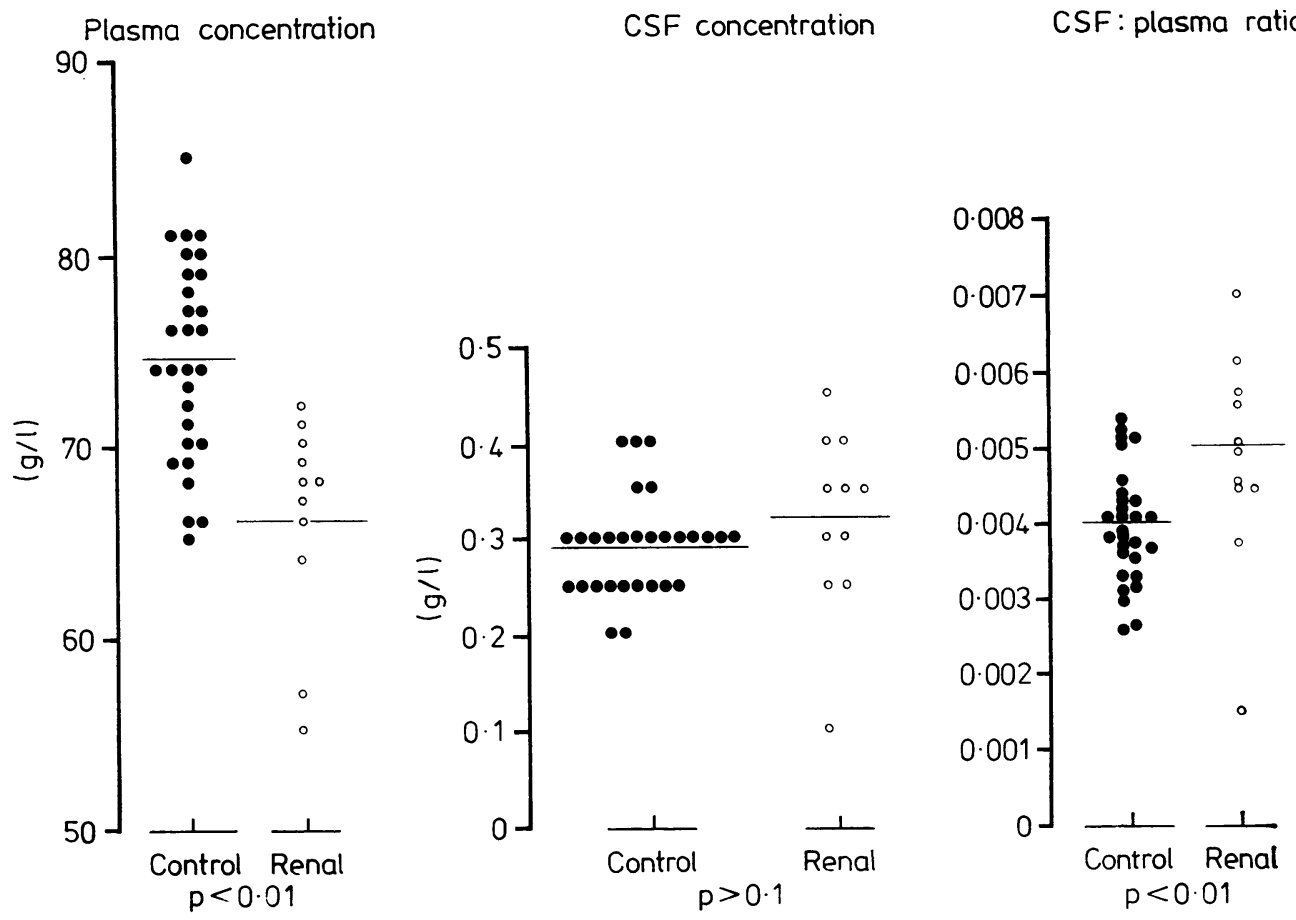

Fig. 2 Plasma and CSF concentrations and CSF:plasma concentration ratios of protein in control subjects and patients with chronic renal failure.

(Fig. 2). For the other inorganic ions, two patterns of change from normal were found in "steady-state" chronic renal failure:

Changes in plasma accompanied by changes in CSF In the renal patients, the mean chloride concentrations of plasma $(108.5 \mathrm{mmol} / \mathrm{l})$ and CSF $(129 \cdot 2$ $\mathrm{mmol} / \mathrm{l})$ were both higher than in the control subjects in whom the plasma mean value was $103.0 \mathrm{mmol} / \mathrm{l}$ $(0.05>\mathrm{p}>0.02)$ and the CSF mean concentration $123.1 \mathrm{mmol} / \mathrm{l}(\mathrm{p}<0.01)$. Since the percentage increases were similar in both fluids the CSF:plasma ratio was within normal values. A positive correlation was found between the CSF and plasma chloride concentration $(p<0.05)$.

In the patients with renal failure, the plasma mean potassium concentration was $4.85 \mathrm{mmol} / 1$ (range 4.00-6.00) compared with the control value of 3.96 mmol/l (range 3.50-4.70) $(p<0.01)$. In CSF the mean concentration of potassium was $3.06 \mathrm{mmol} / 1$ (range 2.60-3.50) compared with $2.84 \mathrm{mmol} / 1$ (range 2.40-3.00) in the control subjects $(0.02>\mathrm{p}>0.01)$. As these values in patients with chronic renal failure represent a $22.5 \%$ difference in plasma concentration compared with the control subjects, but only a $7 \cdot 7 \%$ difference for the CSF level, the CSF:plasma ratio for potassium was significantly lower than normal in renal failure with the ratios of 0.72 and 0.65 respectively $(0.02>p>0.01$ ) (Fig. 1). The CSF potassium concentration in the renal patients showed a positive correlation with its concentration in plasma $(\mathrm{p}<0.001)$ (Table 3$)$.

Changes in plasma not accompanied by changes in CSF

Although the mean plasma concentration of $D$ magnesium was $1.02 \mathrm{mmol} / 1$ in renal failure compared with $0.83 \mathrm{mmol} / 1$ in control subjects $\tilde{\sigma}$ $(p<0.01)$, the mean CSF concentration did not differ significantly in the two groups. Similarly a lower mean plasma calcium concentration than $\omega$ normal occurred in renal failure (1.95 compared with $2.38 \mathrm{mmol} / 1, \mathrm{p}<0.01$ ) but the mean CSF calcium 0 level did not vary from the normal value. The CSF: $\mathbb{D}$ plasma ratio of calcium was higher than normal in $\stackrel{+}{-}$ the renal patients $(0.72$ compared with $0.55 ;$ 웅 $\mathrm{p}<0.01$ ) but for magnesium the ratio was not significantly different (Figs. 3 and 4). No cor- $\stackrel{\square}{\Omega}$ relation between the CSF and plasma concentrations $\stackrel{\square}{\square}$ of calcium or magnesium was found in the patients with renal failure (Table 3). 


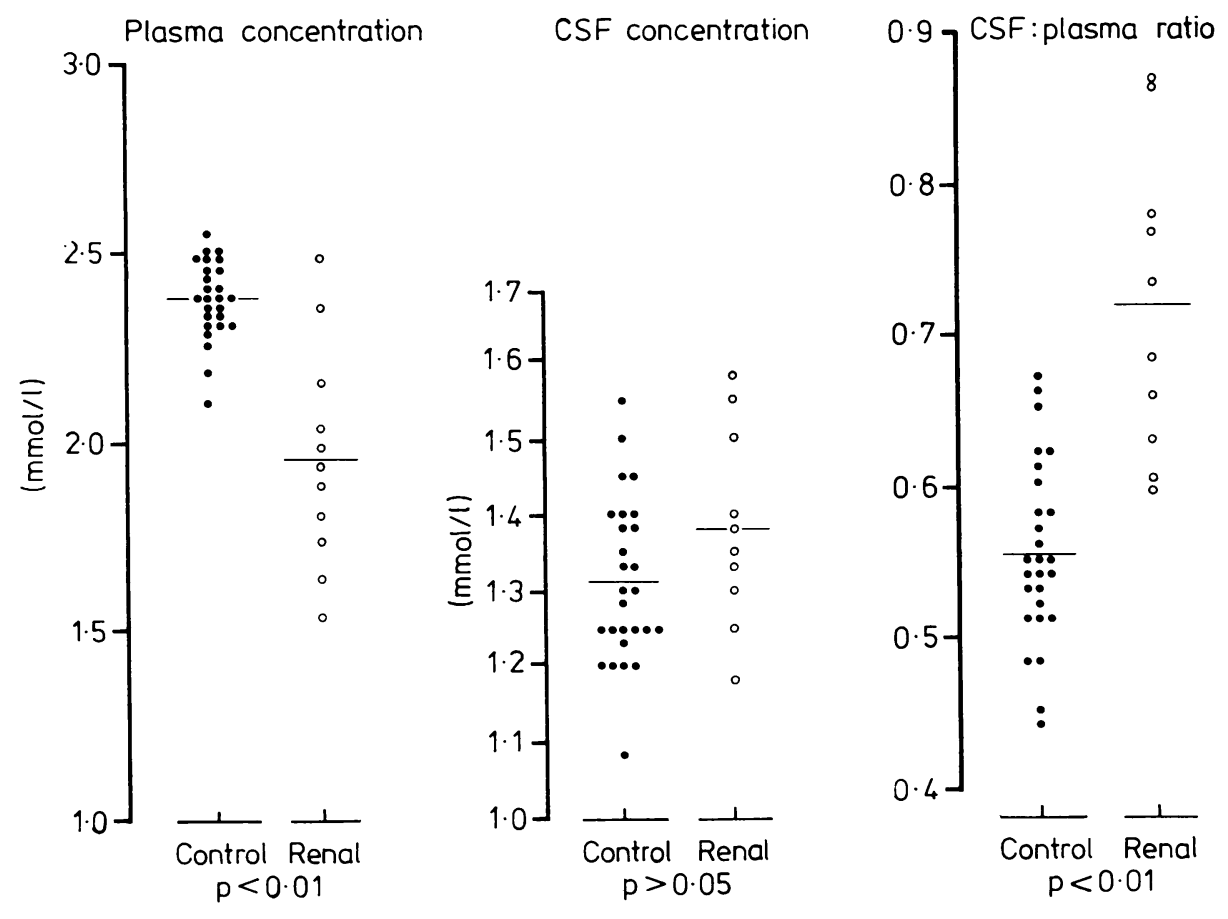

Fig. 3 Plasma and CSF concentrations and CSF:plasma concentration ratios of calcium in control subjects and patients with chronic renal failure.

\section{INFLUENCE OF PLASMA pH}

The anion gap (calculated as the sum of the sodium and potassium concentrations minus the chloride concentration) was significantly lower in CSF than plasma in both control subjects and renal patients (control plasma $40.8 \pm 2.6 \mathrm{mmol} / 1$, control CSF $26.9 \pm 2.8 \mathrm{mmol} / 1, \mathrm{p}<0.01$; renal plasma $38.1 \pm$ $3.3 \mathrm{mmol} / \mathrm{l}$, renal CSF $23.1 \pm 4.3 \mathrm{mmol} / \mathrm{l}, \mathrm{p}<0.01$ ). The anion gap was lower than normal in the plasma ( $p<0.02)$ and in the CSF $(p<0.01)$ in renal failure. Measurements of CSF pH were not available but the influence of plasma $\mathrm{pH}$ on plasma and CSF concentrations of inorganic ions and on their CSF: plasma concentration ratios in chronic renal failure was assessed by linear regression analysis. For plasma no positive correlations were found but in CSF, the chloride concentration showed a positive correlation with plasma hydrogen ion concentration ( $r=0.746 ; p<0.01$ ). Of the CSF:plasma ratios, only that of calcium had a positive correlation with plasma hydrogen ion concentration $(r=0.915$; p $<0.001$ )

INTERRELATIONS BETWEEN THE CSF AND PLASMA CONCENTRATIONS OF THE

INORGANIC IONS

If the concentration of a solute is related directly to the plasma concentration and there is no constant term in the simple equation relating the two, then the population regression coefficient will equal the population mean CSF:plasma concentration ratio. 4 For all the inorganic ions measured in both control subjects and patients with renal failure, the observed regression coefficients differed significantly from the mean CSF:plasma concentration ratios ( $\mathrm{p}<0.001-$ $\mathrm{p}<0.01$, Table 3).

\section{Discussion}

The CSF concentrations of inorganic ions and glucose in the control subjects of the present study are comparable with those in published reports. ${ }^{4-8}$ The mean CSF concentration of potassium was lower than that of plasma and the range was smaller. This indicates a relative stability of CSF potassium and linear regression analysis showed that the concentration of potassium in the CSF of the normal subjects is independent of that in plasma. This accords with the findings of Bradbury et al. ${ }^{4} \mathrm{~A}$ similar independence of CSF and plasma concentrations has been demonstrated for calcium and magnesium in this study and has been reported by others. $^{9}$

The present study has also demonstrated that in 

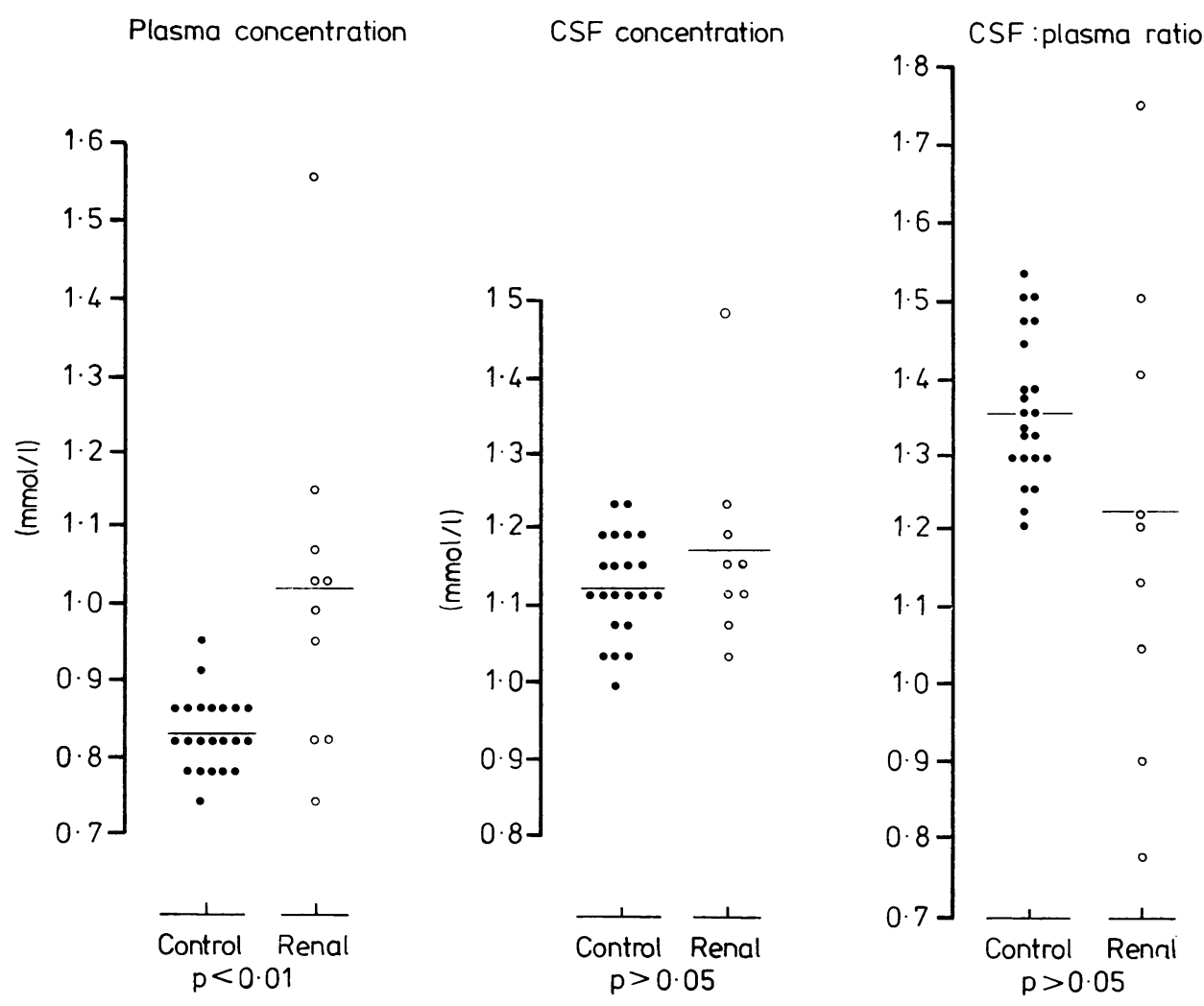

Fig. 4 Plasma and CSF concentrations and CSF:plasma concentration ratios of magnesium in control subjects and patients with chronic renal failure.

the face of long-standing plasma abnormalities in "steady-state" chronic renal failure, homeostasis of some CSF constituents but not of others has been preserved. Although significant alterations of the plasma concentrations of potassium, chloride, calcium, magnesium and protein occurred, corresponding CSF changes were noted only in the cases of potassium and chloride. $A$ rise in the CSF potassium concentration was associated with a raised plasma concentration and a positive correlation was shown between the CSF and plasma concentrations of this ion in renal failure. In the control subjects no correlation was found between the CSF and plasma potassium concentrations within the range of plasma concentrations of 3.50 to $4.70 \mathrm{mmol} / \mathrm{l}$. The regression lines for CSF and plasma potassium concentrations are not comparable in the renal patients and control subjects because of the lower range of plasma potassium concentrations in the latter. To enable a direct comparison of the interrelation of CSF and plasma potassium concentrations in the control subjects and renal patients, the data should include CSF potassium concentrations from controls with plasma potassium concentrations greater than $5.0 \mathrm{mmol} / \mathrm{l}$. Such data would be difficult to obtain since most normal plasma potassium concentrations fall below 5.0 $\mathrm{mmol} / \mathrm{l}$. In healthy dogs, CSF potassium concentrations are very stable and marked experimental raising or lowering of plasma potassium concentration is not followed by a change in the concentration of CSF potassium. ${ }^{10}$ Therefore, with the reservations indicated, the results in the present study imply that in chronic renal failure the interrelation between CSF and plasma potassium concentrations differs from normal. When plasma is dialysed against an appropriate protein-free saline solution, the distribution of an ion may be expressed as the ratio:

\section{$\frac{\text { Concentration in plasma dialysate }}{\text { Concentration in plasma }}\left(\mathbf{R}_{\text {dial }}\right)$.}

The mean CSF:plasma concentration ratio of potassium in renal failure differed from the $\mathbf{R}_{\text {dial }}$ 
value of $0.96^{11}$ and there was a significant difference between the regression coefficient and the CSF: plasma ratio. Although the plasma may exert a more direct influence on the CSF potassium concentration in renal failure, possibly as a result of altered hydrogen ion concentration in plasma and CSF, there are still restrictions governing potassium exchange between the two compartments.

In contrast to the findings for potassium, the stability and independence from plasma of the CSF calcium and magnesium concentrations have been maintained in renal failure.

There is general agreement that the CSF concentrations of potassium, magnesium and calcium vary much less than those of plasma when acute or chronic disturbances of the latter occur in a clinical setting or are induced experimentally. Limited information is available about the CSF electrolytes in chronic renal failure and the changes in potassium described in the present study have not been reported previously. In a group of uraemic subjects studied by Cooper, Lechner and Bellet, ${ }^{10}$ the CSF potassium concentration remained within a narrow range in spite of wide variations in serum potassium concentrations. No clinical details are stated. The paper does not quote serum or CSF urea or creatinine concentrations and it is uncertain whether the patients were in "steady-state" renal failure. Prill12 has reported a relative stability of the CSF potassium in renal failure but his patients did not form a homogeneous group and no statistical analysis of the data is given. More recently, investigation of 14 patients with chronic renal failure demonstrated no abnormality of CSF sodium or potassium concentrations. ${ }^{13}$

It has been known for a long time that meningeal inflammation causes a marked breakdown of the blood-CSF barrier, ${ }^{11}$ and the CSF may then behave as a diffusate of plasma with regard to its electrolyte content. ${ }^{14-16}$ In meningitis, the CSF concentrations of calcium and magnesium approach their respective plasma concentrations and obey the "law of meningitis". 11 In contrast to the pattern in meningitis, restricted changes of the CSF inorganic ion content have been demonstrated in chronic renal failure by the present study and the findings are analogous, in this respect, to the selective CSF amino acid abnormalities found in the same group of patients. ${ }^{1}$ It is not understood fully how cation homeostasis of CSF is maintained but transport processes are involved. ${ }^{9}$ It has been suggested that although secretion of a fluid of constant composition by the choroid plexus may be a major factor in controlling the concentrations of calcium and magnesium in CSF, this accounts only partly for potassium homeostasis. ${ }^{9}$ Our results imply that the mechanisms for maintaining the CSF potassium concentration differ from those for calcium and magnesium.

The clinical relevance of these disturbances of the CSF inorganic ions is uncertain but it would not seem unreasonable to suggest that they could have either a direct effect on neuronal function or a secondary influence on the transfer of other biochemical moieties-for example, amino acids, at the blood-brain and blood-CSF barriers when this depends on carrier systems linked to ion transport.

\section{References}

${ }^{1}$ Pye IF, McGale EHF, Stonier C, Hutchinson EC, Aber GM. Studies of cerebrospinal fluid and plasma aminoacids in patients with steady-state chronic renal failure. Clin Chim Acta 1979;92:65-72.

${ }^{2}$ Armitage P. Statistical methods in medical research. Oxford, London, Edinburgh, Melbourne: Blackwell Scientific Publications, 1972:122-6.

${ }^{3}$ Cooper BE. Statistics for experimentalists. London: Pergamon Press, 1969:279-80.

${ }^{4}$ Bradbury MWB, Stubbs J, Hughes IE, Parker P. The distribution of potassium, sodium, chloride and urea between lumbar cerebrospinal fluid and blood serum in human subjects. Clin Sci 1963;25:97-105.

${ }^{5}$ Helmsworth JA. Potassium content of normal cerebrospinal fluid. J Lab Clin Med 1947;32:1486-90.

- Shaw CW, Holley HL. Sodium and potassium concentration in human cerebrospinal fluid. J Lab Clin Med $1951 ; 38: 574-6$.

${ }^{7}$ Hunter G, Smith HV. Calcium and magnesium in human cerebrospinal fluid. Nature 1960;186:161-2.

${ }^{8}$ Heipertz R, Eickhoff K, Karstens KH. Magnesium and inorganic phosphate content in cerebrospinal fluid related to blood-brain barrier function in neurological disease. J Neurol Sci 1979;40:87-95.

${ }^{9}$ Bradbury M. Transport and homeostasis of ions in cerebral fluids. In: The concept of a blood-brain barrier. Chapter 8. London, Chichester, New York: Wiley, 1979: 221-31 and 237-46.

10 Cooper ES, Lechner E, Bellet S. Relations between serum and cerebrospinal fluid electrolytes under normal and abnormal conditions. Am J Med 1955;18:613-21.

11 Davson H. Physiology of the cerebrospinal fluid. London: Churchill, 1967:41 and 292-6.

12 Prill A. Die neurologische Symptomatologie der Niereninsuffizienz. Schriftenr Neurol 1969;Band 2:60-70.

${ }^{13}$ Garcia JF, Navarro IR. Constantes del equilibrio ácidobase y de algunos cationes en el liquido cefalorraquideo de pacientes con insuficiencia renal crónica descompensada. Rev Clin Esp 1975;137:229-35.

14 Greenfield JG, Carmichael EA. The cerebrospinal fluid in clinical diagnosis. London: Macmillan and Co Ltd, 1925.

15 Bourdillon RB, Fischer-Williams M, Smith HV, Taylor $\mathrm{KB}$. The entry of radio sodium and of bromide into human cerebrospinal fluid. $J$ Neurol Neurosurg Psychiatry 1957;20:79-97.

16 Sambrook MA. The relationship between cerebrospinal fluid and plasma electrolytes in patients with meningitis. $J$ Neurol Sci 1974;23:265-73.

Requests for reprints to: Dr IF Pye, Department of Neurology, Leicester Royal Infirmary, Leicester LE1 $5 \mathrm{WW}$, England. 